\title{
The Audit Quality and Audit Delay: Evidence from Indonesia
}

\section{T. Husain ${ }^{1 *}$, I. Gusti Ayu Intan Saputra Rini ${ }^{2}$}

${ }^{1}$ Doctoral Program Students, Faculty of Economics and Business, University of Persada Indonesia Y.A.I, Jakarta, Indonesia

${ }^{2}$ Departement of Accounting, Faculty of Economics and Business, University of Warmadewa, Bali, Indonesia

*Corresponding author: thusain050686@gmail.com

DOI: https://doi.org/10.38157/business-perspective-review.v2i3.195

Citation: Husain, T. \& Rini, I. G. A. I. S. (2020). The Audit Quality and Audit Delay: Evidence from Indonesia. Business Perspective Review 2(3), 22-32. DOI: https://doi.org/10.38157/business-perspective-review.v2i3.195

\section{Research Article}

\section{Abstract}

Purpose: This study specifically aims to identify the impact of Audit Quality on Audit Delay. Audit Quality is measured by the proxy log natural fee audit (LNFE).

Methods: This is a causal research with quantitative analysis. This study involves six companies listed in the sub-sectors of Cable under the manufacturing sector in the Indonesia Stock Exchange for the period of 2013-2019. It applied panel data set in a regression model using STATA MP - Parallel Edition Ver14.00 application.

Results: The findings show that the Audit quality has a significant negative impact on the Audit Delay with an average delay of 83.62 days.

Implications: This study could be extended further by considering all manufacturing firms of IDX which may provide more insight into the audit quality with other proxies.

Keywords: Audit Quality; LNFE; Audit Delay

\section{Introduction}

The financial information, such as analyzing investments, deciding whether to provide a loan or not, and deciding other matters related to business activities are very much important to the stakeholders. Audit organizations are facing considerable pressure to submit the financial reports due to increasingly fierce business competition. The application of information technology-based auditing is increasingly needed, especially in developed and developing countries (Husain, 2017). Under the terms of the Company and Allied Matter Act (CAMA) 2004 in Indonesia, every company requires that financial reports are presented to shareholders within no more than fifteen months after the last annual general meeting (Modugu, Eragbe, \& Ikhatua, 2012). Timeliness of financial reporting is a fundamental element of an adequate recording of financial statements. Users of accounting information need not only have relevant financial information for prediction and decision making, but the data must also be of recent origin (Lee, Mande, \& Son, 2009; Wiyantoro \& Usman, 2018).

The Government Accounting Standards Board (GASB) released a survey in 2011, stating that 
stakeholders' financial information would be decreased to 45-90 days. The information provided in 45 days is beneficial for the stakeholders (Henke \& Maher, 2016). Furthermore, several regulations in the last seven years were governing the issuance of audited financial reports for the period. Simultaneously, the Security and Exchange Commission (SEC) stipulates a maximum of 60 days, which was previously 90 days (Lehtinen, 2013). The Securities and Exchange Commission released Form 10-Q, which requires a period after the end of the state territory reporting year to release independent auditor reports with a classification of 3 categories within 60 days, 75 days, and 90 days to the legislature (Fischer \& Marsh, 2018).

The Security and Exchange Commission (SEC) in Nigeria reduced the delay in financial statements from 6 months to 3 months to meet the demands of the stakeholder (Dabor \& Uyagu, 2018). The General Auditing Commission (GAC) Act, 2014 in Liberia in clause 37 (sub-section of 2), and the Public Financial Management (PFM) Act, 2009 mandate the Ministry of Finance and Development Planning that no later than four (4) months after the end of the fiscal year associated with the audit statement in its final calculation (Fully \& David, 2020). The Securities and Exchange Commission in Indonesia (referred to as "OJK") through the OJK Regulation Number 29 / POJK.04 / 2015, in section III of the clause, states that announcement and reporting determines the Issuer or Public Companies for the first time no later than 3 (three) months (OJK Regulations, 2015), and the responsibility of APF through the OJK Regulation Number 13 / POJK.03 / 2017, in clause 20 (3) states that PAF submits a report on the provision of PAF services accompanied by supporting evidence no later than April $15^{\text {th }}$ of every year (OJK Regulations, 2017). The above regulations will have a significant impact, especially for public companies and the timeliness of releasing independent auditors' reports to improve audit quality and shorten audit delays.

The Government of Indonesia in the 2015-2019 National Medium-Term Development Plan (RPJMN) documents the need for community electricity with a capacity of 35,000 megawatts (MW) (Brama, 2019). Several national cable companies have started to develop their businesses and are playing an active role in supporting the government program. They are actively participating in every tender held for the construction of new projects for the procurement of goods and services in the development of electricity and telecommunications infrastructure in Indonesia. This certainly opens up opportunities for companies to continue to improve their performance and transparency in releasing their audit reports promptly, as stipulated in OJK regulations. Until the end of July $31^{\text {th }}$, 2020. Several Cable sub-sector companies listed on the IDX and found to delay in submitting their financial reports in 2019, even though they always meet other requirements/provisions of OJK.

Table 1: Audit Delay Data on Sub-Sector of Cable Companies in Indonesia

\begin{tabular}{|ccc|}
\hline Ticker Code & Audit Opinion, Date & Audit Delay \\
\hline CCSI & March $20^{\text {th }} 2020$ & $\mathbf{8 0}$ days \\
\hline IKBI & July $10^{\text {th }}, 1990$ & $\mathbf{1 0 1}$ days \\
\hline JECC & April $27^{\text {th }}, 2020$ & $\mathbf{1 1 8}$ days \\
\hline KBLI & April $6^{\text {th }}, 2020$ & $\mathbf{9 7}$ days \\
\hline KBLM & March $27^{\text {th }}, 2020$ & $\mathbf{8 7}$ days \\
\hline SCCO & March $20^{\text {th }} 2020$ & $\mathbf{8 0}$ days \\
\hline VOKS & April $27^{\text {th }}, 2020$ & $\mathbf{1 0 0}$ days \\
\hline
\end{tabular}

Source: Processed data from IDX, 2020 
This condition will certainly much disturb the master plan of RPJMN in Indonesia, which, of course, will require good audit quality and speed up audit reporting to the public. This study specifically aims to identify the audit quality and audit delay in the Cables companies listed in the Indonesia Stock Exchange (IDX), that have implemented IFRS-based reporting standards for the period of 2013 to 2019. This study uses the audit honorarium (LNFE proxy) as an audit quality.

\section{Literature Review}

\subsection{Audit Quality}

The Audit Quality is an applied concept derived from the Theory of Reasoned Action (TRA) introduced by Martin Fishbein and Icek Ajzen in 1975. TRA theory states that attitude toward behavior refers to the degree to which a person has a favorable or unfavorable evaluation of the action in question. This theory is used extensively to predict the belief factors that influence knowledge sharing behavior (Ryu, Ho, \& Han, 2003; Tandiontong, 2016, hal. 29).Audit Theory (Auditing Theory) deals with the audit of financial statements (general audit). This needs to be differentiated from other audit services performed by an independent auditor or public accounting firm (PAF) (p. 31). In the practical literature, audit quality is how well the audit conforms to the auditing standard.

Audit quality is tough to define and measure, which sparks a lot of debate in academia (Francis, 2011; Svanström, 2013; Donovan, Frankel, Lee, Martin, \& Seo, 2014; Qi, Li, \& Tian, 2015; Raak \& Thürheimer, 2016; Husain, 2020). Audit quality is the probability that auditors will discover the company's accounting system's transgression and report them (DeAngelo, 1981). Audit quality is measured based on the audit engagement indicators, and the accounting firm's characteristics regularly reported to the Advisory Committee on the Auditing Profession (ACAP) (Bedard, Johnstone, \& Smith, 2010). Audit quality is determined comprehensively by PAF, auditors, and regulators entanglement (Francis, 2011). Audit quality has a relationship with good corporate governance, internal control, and longer audit tenure factors (Hay, 2013).

Audit quality reflects the rule view that higher audit quality will be better concerning client financial reporting quality (Donovan, Frankel, Lee, Martin, \& Seo, 2014). Audit quality depends on the judgments based on evaluation of evidence, audit testing, and audit report formulation as determined by the auditor (Qi, Li, \& Tian, 2015). It is determined based on the audit's input, the audit process, and the outputs arising from the audit process and the characteristics and relationships with the client (Raak \& Thürheimer, 2016). Audit quality needs to emphasize the audit function's effectiveness to stakeholders and other investors to maintain its quality and avoid future corporate scandals (Ukoma, 2020).

The broad definition, measurement, and output of audit quality are mostly determining the amount of honorarium received by PAF or external auditors, as stated in the audit engagement and its terms and conditions. Furthermore, the measurement of audit quality under the PAF (Big-4 non-Big-4) category and audit fee does not significantly differ in the context of public companies in Indonesia (Husain \& Syniuta, 2020). 


\subsection{Audit Delay}

Audit delay is the delay in timeliness of delivering information that may affect the reported data's usability for decision-making (Ashton, Willingham, \& Elliott, Autumn, 1987). In Cambridge Dictionary, a delay is when a person has to wait for more than what is expected to happen to a condition. Givoly (1982) states that audit delay is caused by a material mismatch between the auditor and the client regarding accounting practices and accounting numbers calculation, called abnormal audit delay. Abnormal audit delay is a measurement of audit delay that cannot be identified by reviewing the determinant factors (Dabor \& Uyagu, 2018). Audit delay is the constraint that occurs during the audit process, such as inefficiency in issuing financial reports (Super \& Shil, 2019).

\subsection{Hypotheses Development and Research Model}

\subsubsection{Hypotheses Development}

Audit delay is the period required for PAF to process audit activities in releasing independent auditor reports. This report is essential to various stakeholders such as regulators, investors, creditors, shareholders, tax authorities, potential investors, and others. The delay in releasing the independent auditor's report is inseparable from the PAF audit's good or bad quality. It can be seen that companies generally tend to delay releasing audited financial statements when they predict the audit results. This condition is caused by many factors, such as the findings of previous studies viz.: (1) Audit lag has positive dealings with the amount of audit work required, where a higher audit effort has an impact on improving the quality of a better audit (Bryant-Kutchera, Peng, \& Weber, 2013); (2) Postponement of the prior audit with an essence of the timeliness of the audit report that is not only predicted by financial variables, but also nonfinancial variables (Fischer \& Marsh, 2018); (3) Deadlines can reduce audit delays by the regulatory board, and PAF must accommodate a lot of work in the early period of the year by hiring more staff to handle the audit workload (Super \& Shil, 2019). The factors above have been included in the audit engagement guided by the General Acceptance Audit Standards (GAAS). They are contained in the honorarium required to complete the audit period and its terms and conditions. The hypothesis of the study is stated below:

Ha: Audit quality has a significant impact in the context of audit delay.

\subsubsection{Research Model}

This study aims to investigate the impact of audit quality on audit delay. Thus, the research model includes audit quality as the independent variable $(X)$ and audit delay as the dependent variable $(\mathrm{Y})$ which is shown in the following diagram.

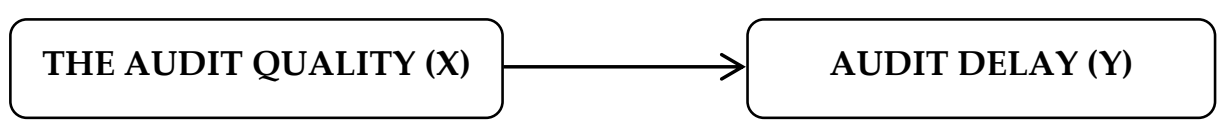

\section{Fig.1. The Research Model}




\section{Methodology}

This research tests a hypothesis that explains a causal relationship between dependent and independent variables (Supranto \& Limakrisna, 2019, p. 3). This research uses a quantitative research approach. The population of this research includes the manufacturing sub-sectors of Cables (6 companies) listed in the Indonesia Stock Exchange (IDX) in 2019. One more company was added to the list in the latter half of 2019. But it was excluded for the study. The data were collected from all 6 companies for the period of 2013-2019. The number of observations were calculated by multiplying the number of samples across the research period, namely, seven years multiplied by six company samples, i.e., forty-two observation data.

Table 2: Research Sample

\begin{tabular}{|ccc|}
\hline Ticker Code & IPO Date & Issuer Name \\
\hline CCSI & June $18^{\text {th }} 2019$ & PT Communication Cable Systems Indonesia Tbk \\
\hline IKBI & January $21^{\text {th }} 1990$ & PT Sumi Indo Cable Tbk \\
\hline JECC & November $18^{\text {th }} 1992$ & PT Jemblo Cable Company Tbk \\
\hline KBLI & July $6^{\text {th }} 1992$ & PT KMI Wire and Cable Tbk \\
\hline KBLM & July $1^{\text {st }} 1992$ & PT Kabelindo Murni Tbk \\
\hline SCCO & July $20^{\text {th }} 1982$ & PT Supreme Cable Manufacturing and Commerce Tbk \\
\hline VOKS & December $20^{\text {th }} 1990$ & PT Voksel Electric Tbk \\
\hline
\end{tabular}

Source: Saham OK, 2020

The independent variable $(X)$ in this study is the audit quality using the LNFE proxy, namely the log natural fee audit (Chung \& Lindsay, 1988; Bedard, Johnstone, \& Smith, 2010; DeFond \& Zhang, 2014; Sarhan, Ntim, \& Al-Najjar, 2019; Husain \& Syniuta, 2020) while dependent variable $(\mathrm{Y})$ is audit delay, i.e., a difference of days between the end of the firm's financial year and the date of the independent auditor's report letter (Cohen \& Leventis, 2013; Fischer \& Marsh, 2018).

This research method uses a panel data set in the regression model with the STATA MP Parallel Edition Ver14.00 application. The regression model formulated as follows:

$$
\begin{aligned}
& \mathrm{Y}=\alpha+\beta \mathrm{X}+\mathrm{e} \\
& \text { Explanation: } \\
& \mathrm{Y}: \text { The Audit Quality } \\
& \mathrm{X}: \text { Audit Delay } \\
& \alpha: \text { Constant } \\
& B: \text { Coefficients } \\
& \varepsilon: \text { Error }
\end{aligned}
$$

\section{Findings and Analysis}

\subsection{Descriptive Statistics}

Create PLS-Table, which proceeds the following output: 


\begin{tabular}{|c|c|c|c|c|c|c|c|}
\hline & Y X & & & & & & \\
\hline & & Mean & Std. Dev. & Min & $\operatorname{Max}$ & Obse: & Lons \\
\hline$Y$ & overall & 83.61905 & 11.80317 & 45 & 118 & $\mathrm{~N}=$ & 42 \\
\hline & between & & 6.331435 & 72.71429 & 89.57143 & $\mathrm{n}=$ & 6 \\
\hline & within & & 10.25154 & 55.90476 & 112.1905 & $\mathrm{~T}=$ & 7 \\
\hline $\mathrm{x}$ & overall & 20.05245 & .6935116 & 18.45024 & 21.15505 & $\mathrm{~N}=$ & 42 \\
\hline & between & & .6253639 & 19.1433 & 20.74933 & $\mathrm{n}=$ & 6 \\
\hline & within & & .3835487 & 19.35939 & 21.26554 & $\mathrm{~T}=$ & 7 \\
\hline
\end{tabular}

Fig.2. The descriptive test results per variable

The Audit Quality (X) with the LNFE proxy has an average value of 20.05245 squads, with a standard deviation of 0.6935116 squads. In other words, the six companies had relatively high LNFE's. Audit Delay (Y) has an average value of 83.62 days, with a standard deviation of 11.80 days. In other words, the six companies included in the research had relatively short audit delay as per the provisions required by the OJK.

\subsection{Display of Balance Panel Data}

PLS model provides the following output:

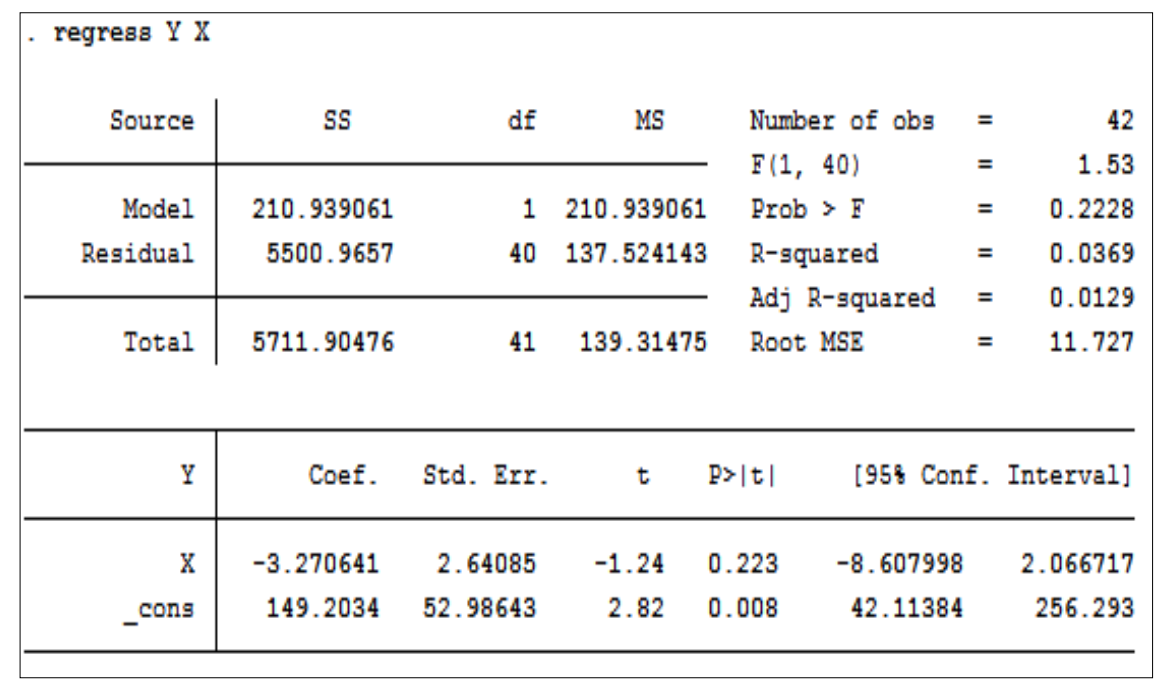

Fig.3. The PLS Model

The panel data provides the following regression equation:

$$
\mathrm{Y}=149.2034-3.270641 \mathrm{X}+\mathrm{e}
$$

\subsection{Estimation of Panel Data Regression}

The Chow test is used of paired data regression model testing between Common-Effect Model (CEM) and Fixed-Effect Model (FEM). If the probability F > 0.05, H0 is supported (choose Common-Effect Model or vice versa). The test result provides the following output: 


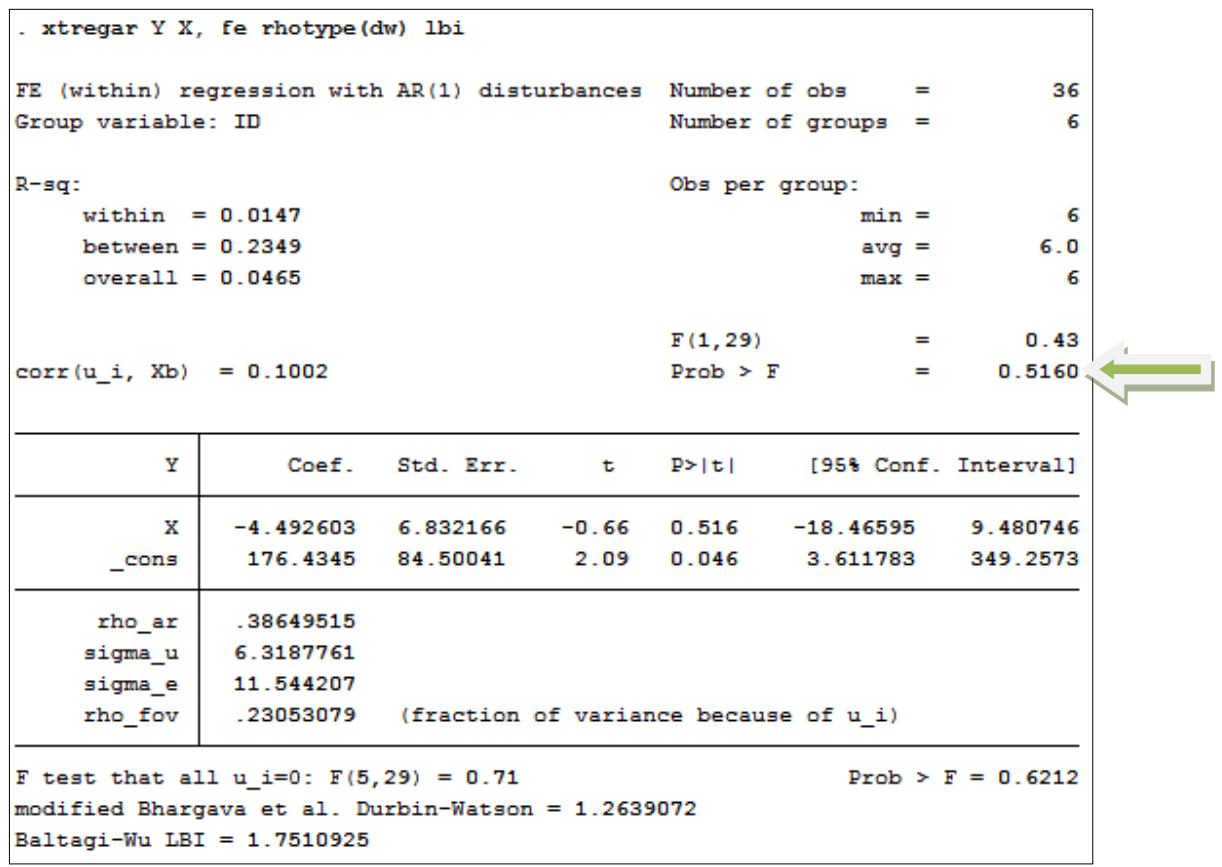

Fig.4. Chow Test Result

Interpretation: $\mathrm{H}_{\mathrm{o}}$ is supported, with a significant probability of $\mathrm{F}$ is 0.5160 (more than 0.05 ), then select the Common-Effect Model.

The Hausman's method is used for paired data regression model testing between Fixed-Effect Model (FEM) and Random-Effect Model (REM). If the probability F Chi-Square > 0.05, H0 is supported (choose Random-Effect Model or vice versa). The test result provides the following output:

\begin{tabular}{|c|c|c|c|c|c|c|}
\hline \multicolumn{7}{|c|}{ - xtregar $\mathrm{Y} \mathrm{X}$, re rhotype (theil) $1 \mathrm{bi}$} \\
\hline \multirow{2}{*}{\multicolumn{3}{|c|}{$\begin{array}{l}\text { RE GLS regression with AR(1) disturbances } \\
\text { Group variable: ID }\end{array}$}} & \multirow{3}{*}{\multicolumn{3}{|c|}{$\begin{array}{l}\text { Number of obs }= \\
\text { Number of groups }= \\
\text { Obs per group: }\end{array}$}} & 42 \\
\hline & & & & & & 6 \\
\hline \multicolumn{3}{|l|}{$\mathrm{R}-\mathrm{sq}$ : } & & & & \\
\hline within & 0.0007 & & \multicolumn{3}{|r|}{$\min =$} & 7 \\
\hline between & 0.2454 & & \multicolumn{3}{|r|}{ avg $=$} & 7.0 \\
\hline overall & 0.0369 & & \multicolumn{4}{|c|}{$\max =$} \\
\hline $\operatorname{corr}\left(u_{-} i, \mathrm{Xb}\right)$ & \multicolumn{2}{|c|}{$=0$ (assumed) } & \multicolumn{3}{|c|}{$\begin{array}{l}\text { Wald chi2 (2) } \\
\text { Prob > chi2 }\end{array}$} & $\begin{array}{r}1.26 \\
0.5338\end{array}$ \\
\hline $\mathrm{Y}$ & Coef. & Std. Err. & $\mathrm{p}>|\mathbf{z}|$ & \multicolumn{2}{|c|}{ [958 Conf. } & Interval] \\
\hline $\mathrm{x}$ & -3.259938 & 2.909519 & 0.263 & \multicolumn{2}{|c|}{-8.96249} & 2.442614 \\
\hline _cons & 149.2293 & 58.38163 & 0.011 & \multicolumn{2}{|c|}{34.8034} & 263.6552 \\
\hline rho_ar & .14349003 & \multirow{2}{*}{\multicolumn{4}{|c|}{ (estimated autocorrelation coefficient) }} & \\
\hline sigma_u & 1.5715132 & & & & & \\
\hline sigma_e & 10.863637 & & \\
\hline rho_fov & .02049705 & & & & & \\
\hline theta & .0519534 & \multicolumn{4}{|c|}{ (Iraction of variance due to u_-1) } & \\
\hline
\end{tabular}

Fig.5. Hausman's Test Result 
Interpretation: $H_{0}$ is supported, with a significant probability of Chi-Square is 0.5338 (more than 0.05), then select the Random-Effect Model.

The Lagrange Multiplier (LM) test was used to confirm the paired data regression model selection between the Random-Effect Model (REM) and the Common-Effect Model (CEM). If probability chibar2 $>0.05, \mathrm{H} 0$ is supported (choose Random-Effect Model or vice versa). The test results give the following output: The test result provides the following output:

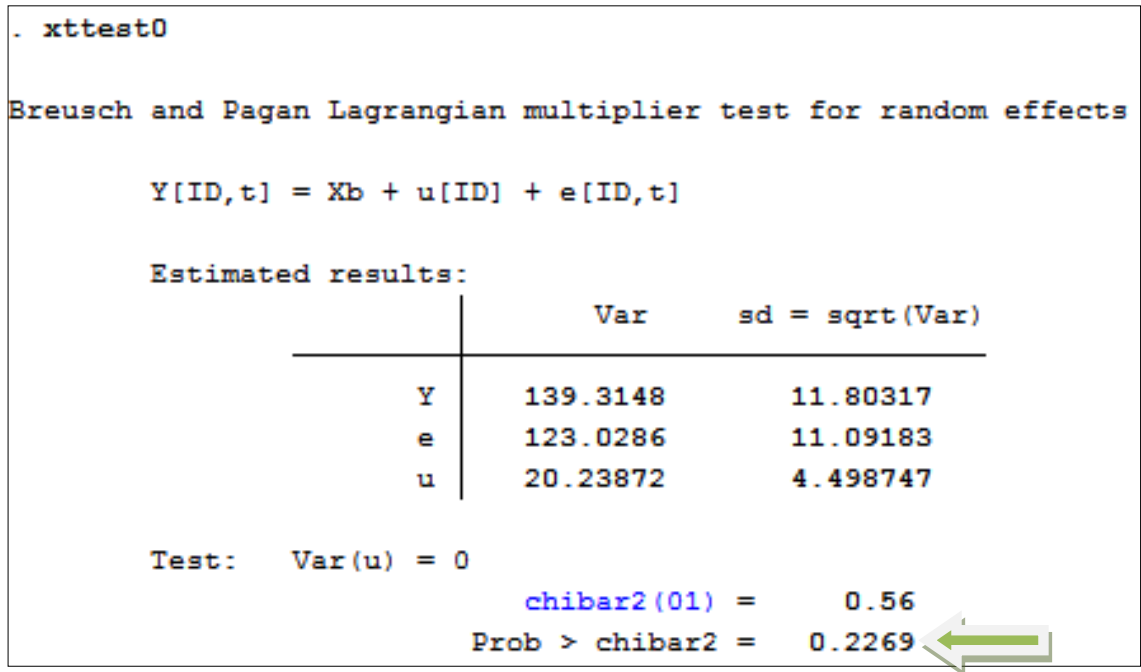

Fig.6. Lagrange Test Result

Interpretation: $H_{0}$ is rejected, with a significant probability of chibar2 is 0.2269 (more than 0.05 ), then select the Random-Effect Model (Final Model).

Because of REM model is chosen, then Random-Effect Generalized Least Squares (GLS) regression (derived from Fig.5), which proceed as follow:

\begin{tabular}{|c|c|c|c|c|c|c|c|c|}
\hline \multirow{2}{*}{\multicolumn{4}{|c|}{$\begin{array}{l}\text { RE GLS regression with AR(1) disturbances } \\
\text { Group variable: ID }\end{array}$}} & \multicolumn{3}{|c|}{ Number of obs } & $=$ & 42 \\
\hline & & & & Number & gro & ups & $=$ & 6 \\
\hline \multicolumn{4}{|l|}{$R-s q$ : } & \multicolumn{5}{|c|}{ Obs per group: } \\
\hline within & 0.0007 & & & & & $\min$ & $\mathrm{n}=$ & 7 \\
\hline between & 0.2454 & & & & & avg & $g=$ & 7.0 \\
\hline overall & 0.0369 & & & & & $\max$ & $\mathrm{x}=$ & 7 \\
\hline \multirow[b]{2}{*}{$\operatorname{corr}\left(u_{-} i, x b\right)$} & \multirow{2}{*}{\multicolumn{2}{|c|}{$=0$ (assumed) }} & & \multirow{2}{*}{\multicolumn{3}{|c|}{$\begin{array}{l}\text { Wald chi2 (2) } \\
\text { Prob > chi2 }\end{array}$}} & $=$ & 1.26 \\
\hline & & & & & & & $=$ & 0.5338 \\
\hline $\mathrm{Y}$ & Coef. & Std. Err. & $\mathrm{z}$ & $\mathrm{P}>|\mathbf{z}|$ & {$[95$} & $8 \mathrm{Co}$ & onf. & Interval] \\
\hline $\mathrm{x}$ & -3.259938 & 2.909519 & -1.12 & 0.263 & -8 . & 9624 & & 2.442614 \\
\hline _cons & 149.2293 & 58.38163 & 2.56 & 0.011 & & .803 & & 263.6552 \\
\hline
\end{tabular}

Fig.7. Random-Effect GLS Regression

The result of alternative hypothesis $(\mathrm{Ha})$ analysis from research model independent variable $(X)$ has a significant probability is more than 0.05 and holds the chi 2 score, viz. 0.5338 , so the Ha is Supported. This means The Audit Quality have a substantial effect in the context of audit delay. 


\subsection{Analysis}

The results of the alternative hypothesis study above proved to have a significant effect. In other words, this study empirically states that audit quality is a factor that impacts audit delay, where audit quality with the proxy LNFE (audit honorarium), can predict audit delays with kind of non-financial variables (Fischer \& Marsh, 2018), with a category of filers less than 90 days, i.e., 83.62 days from descriptive analysis (Fig.2), while the average delay was considerably longer of 228 days in the Greek municipal studies (Cohen \& Leventis, 2013) and audit lag is positively related to the improvement of better audit quality based on the amount of audit work required (Bryant-Kutchera, Peng, \& Weber, 2013). Besides that, the audit report lag in reviews on manufacturing companies of the Nigerian stock exchange (NSE) for the 2010-2012 period shows that audit firm type has no a significant effect on audit delay with an average score is 111.042 days (Azubike \& Aggreh, 2014). In the context of industrial goods companies in Nigeria shows that audit quality has a significant negative effect on audit report delay, which is in line with the findings of this study (Ukoma, 2020). Furthermore, deadlines can reduce audit delays by the supervisory board, and PAF must improve audit quality in handling the audit workload (Super \& Shil, 2019).

\section{Conclusions and Recommendations}

Audit Quality has a significant negative impact on the Audit Delay with an average delay of 83.62 days, it means that the better the audit quality, the shorter the audit delay. The company's evaluation of audit delays must be paid close attention to considering the regulation of the OJK, which requires a deadline for the release of audited financial statements each year. Regulators in Indonesia $(\mathrm{OJK})$ can also evaluate the deadline for submitting reports to the public, who function as monitors.

Future research regarding the audit quality can use alternative measurements such as the "Big4" category public accounting firm (PAF), audit tenure, auditor change, industry specialization (client), and subsidiary.

Author Contributions: T. Husain conceived the idea and collected data; T. Husain and I Gusti Ayu Intan Saputra Rini analyzed the data; T. Husain wrote the paper.

Conflict of Interest: The authors declare no conflict of interest.

\section{REFERENCES}

Ashton, R. H., Willingham, J. J., \& Elliott, R. K. (Autumn, 1987). An Empirical Analysis of Audit Delay. Journal of Accounting Research, 25(2), 275-292.

Azubike, J., \& Aggreh, M. (2014, December). Corporate Governance and Audit Delay in Nigerian Quoted Companies. European Journal of Accounting Auditing and Finance Research, 2(10), 22-33.

Bedard, J. C., Johnstone, K. M., \& Smith, E. F. (2010, March 26). COMMENTARY: Audit Quality Indicators: A Status Update on Possible Public Disclosures and Insights from Audit Practice. Current Issues in Auditing, 4(1), C12-C19. 
Brama, A. (2019, Mei 13). Simak Rekomendasi Analis untuk Emiten Kabel berikut. Retrieved Agustus 1, 2020, from Investasi / Emiten: https://investasi.kontan.co.id/news/simak-rekomendasi-analis-untuk-emiten-kabelberikut

Bryant-Kutchera, L., Peng, E. Y., \& Weber, D. P. (2013, November-December). Regulating the timing of disclosure: Insights from the acceleration of 10-K filing deadlines. Journal of Accounting and Public Policy, 32(6), 475-494.

Chung, D. Y., \& Lindsay, W. D. (1988, April). The Pricing of Audit Services: The Canadian Perspective. Contemporary Accounting Research, $5(1$ (Fall)), 19-46.

Cohen, S., \& Leventis, S. (2013, March). Effects of municipal, auditing and political factors on audit delay. Accounting Forum, 37(1), 40-53.

Dabor, A. O., \& Uyagu, B. D. (2018, June). Abnormal Audit Delay and Earnings Quality in Nigerian. Sriwijaya International Journal of Dynamic Economics and Business, 2(2), 99-108.

DeAngelo, L. (1981, December). Auditor Size and Audit Quality. Journal of Accounting and Economics, 3(3), 183-199.

DeFond, \& Zhang, J. (2014, November-December). A review of archival auditing research. Journal of Accounting and Economics, 58(2-3), 275-326.

Donovan, J., Frankel, R., Lee, J., Martin, X., \& Seo, H. (2014, September). Issues Raised by Studying DeFond and Zhang: What should Audit Researchers do? Journal of Accounting and Economics, 58, 327-338.

ENA. (2012). Electric and Magnetic Fields: The Fact. London: Energy Networks Association.

Fischer, M., \& Marsh, T. (2018). Determinants of State Audit Delay: An Empirical Analysis. Journal of Accounting and Finance, 18(9), 79-97.

Francis, J. (2011, May). A Framework for Understanding and Researching Audit Quality. A Journal of Practice $\mathcal{E}$ Theory, 30(2), 125-152.

Fully, R. B., \& David, K. D. (2020). Causes of Audit Delay and their Effects on Public Sector Audit Quality (A case of the Supreme Audit Institution of Liberia - General Auditing Commission). Faculty of Business. Sweden: Hogskolan Kristianstad.

Hay, D. (2013). Further Evidence From Meta-Analysis of Audit Fee Research. International Journal of Auditing, 17, 162-176.

Henke, T. S., \& Maher, J. J. (2016, December). Government reporting and timeliness and municipal credit market implications. Journal of Governmental \& Nonprofit Accouting, 5(1), 1-24.

Holmlund, M. (2008). A Definition, Model, and Empirical Analysis of Business-To-Business. International Journal of Service Industry and Management, 19(1), 32-62.

Husain, T. (2017). Analisis Determinan Faktor-Faktor Yang Mempengaruhi Niat Penggunaan Software Audit. Jurnal Ilmiah Matrik, 19(2), 131-150.

Husain, T. (2019). An Analysis of Modeling Audit Quality Measurement Based on Decision Support Systems (DSS). European Journal of Scientific Exploration, 2(6), 1-9.

Husain, T. (2020). Mapping Evolution of Audit Quality Measurement. European Journal of Business and Management Research, 5(3), 1-7.

Husain, T., \& Syniuta, A. (2020). Audit Fee and "The Big-Four": A Comparative Study at Initial Public Offerings (IPO) Companies in Indonesia Stock Exchange (IDX). Multidisciplinary European Academic Journal, 2(4), 1-7.

Lee, H.-Y., Mande, V., \& Son, M. (2009, June 09). Do Lengthy Auditor Tenure and The Provision of Non-audit Service by External Auditor Reduce Audit Report lags? International Journal of Auditing, 13, 87-104.

Lehtinen, T. (2013). Understanding timeliness and quality of financial reporting in a Finnish public company. Finlandia: Aalto University, School of Business.

Modugu, K., Eragbe, E., \& Ikhatua, G. (2012, June). Determinants of Audit Delay: Empirical Evidence from Nigeria. The International Journal of Business and Finance Research, 8(2), 21-28.

NSW Department of Planning, Industry and Environment. (2018). Service and Installation Rules of New South Wales: Section 1 - General Requirements. New South Wales: Service and Installation Rules of NSW.

OJK Regulations. (2015). Peraturan Otoritas Jasa Keuangan Nomor 29/POJK.04/2015 tentang Emiten atau Perusahaan Publik yang Dikecualikan dari Kewajiban Pelaporan dan Pengumuman. Jakarta: OJK.

OJK Regulations. (2017). Peraturan Otoritas Jasa Keuangan Nomor13/POJK.03/2017 tentang Penggunaan Jasa Akuntan Publik dan Kantor Akuntan Publik dalam Kegiatan Jasa Keuangan. Jakarta: OJK. 
Qi, B., Li, B., \& Tian, G. (2015, January/February). What Do We Know About The Variance Of Audit Quality? An Empirical Study From The Perspective Of Individual Auditor. The Journal of Applied Business Research, 31(1), 71-88.

Raak, J. v., \& Thürheimer, U. (2016, September). Opportunities to improve the measurement of audit quality: a call for collaboration between the profession and academics. (D. O. Bik RA (Guest Editor), P. d. Bouwens (Guest Editor), P. d. Wallage RA, \& D. C. Knoops, Eds.) Maandblad (MAB) Voor Accountancy en Bedrijfseconomie 90e Jaargang(9), pp. 352-358.

Ryu, S., Ho, S. H., \& Han, I. (2003, July). Knowledge Sharing Behavior of Physicians in Hospitals. Expert Systems With Applications, 25(1), 113-122.

Saham OK. (2020, February 16). Sub sektor kabel (45) - Industri Manufaktur. Retrieved August 28, 2020, from https://www.sahamok.com/emiten/sektor-aneka-industri/sub-sektor-kabel/

Sarhan, A., Ntim, C. G., \& Al-Najjar, B. (2019, Juni). Antecedents of Audit Quality in MENA Countries: The Effect of Firm- and Country-Level Governance Quality. Journal of International Accounting Auditing and Taxation, $35,85-107$.

Super, S. O., \& Shil, N. C. (2019). Effect of Audit Delay on the Financial Statements. Sumerianz Journal of Economics and Finance, 2(4), 37-43.

Supranto, J., \& Limakrisna, N. (2019). Petunjuk Praktis Penelitian Ilmiah untuk Menyusun Skripsi, Tesis dan Disertasi (5 ed.). Bogor: Penerbit Mitra Wacana Media.

Svanström, T. (2013). Non-audit services and audit quality: evidence from private firms. European Accounting Review, 22(2), 337-366.

Tandiontong, M. (2016). Kualitas Audit dan Pengukurannya. Bandung: Alfabeta.

Ukoma, A. P. (2020). The Effect of Audit Quality on Audit Report Lag of Industrial Goods Companies in Nigeria. Journal of African Studies and Sustainable Development, 3(5), 87-99.

Wiyantoro, L., \& Usman, F. (2018). Audit Tenure and Quality to Audit Report Lag in Banking. European Research Studies Journal, XXI(3), 417-428.

(C) 2020 by the authors. Licensee Research \& Innovation Initiative, Michigan, USA. This article is an open-access article distributed under the terms and conditions of the Creative Commons Attribution (CC BY) license (http://creativecommons.org/licenses/by/4.0/). 